\title{
Rethinking educational tourism: proposing a new model and future directions
}

\author{
Christine A. McGladdery \\ Department of Tourism Management, University of Pretoria, Pretoria, South Africa \\ Berendien A. Lubbe \\ Department of Tourism Management, University of Pretoria, Pretoria, South Africa
}

\begin{abstract}
:
Purpose

Educational tourism is under-researched in the literature. This paper argues that this stems from a lack of consensus regarding the nature and scope of educational tourism as a theoretical concept and market segment.

Design/methodology/approach

Through a review of research over the last decade and a half, the paper aims at providing a concise overview of the key perspectives and concepts in educational tourism, whilst highlighting the potential for future directions of the sector.
\end{abstract}

Findings

Ritchie's (2003) segmentation model of educational tourism is usually considered the international standard for writing on the subject. However, it excludes certain sectors of tourism that may be considered educational. In response to this, a new conceptual model is presented.

Further research is needed to understand the schools' educational tourism market. When international educational tourism is considered, the majority of empirical research and academic debate has originated in the closely related field of international education.

Educational tourism has the potential for hybridization with other segments of tourism and non-tourism sectors, and to contribute towards global peace.

Originality/value

This paper offers an alternative process-driven and outcomes-based conceptual model of educational tourism. It identifies directions for future research in schools' and international educational tourism and proposes a typology to aid hybridization of the 
phenomenon with other sectors. Finally, it discusses the potential of educational tourism to foster peace through the integration of global learning into touristic practice.

Key words: educational tourism, international educational tourism, global learning, compassion gap, global peace

\section{Introduction}

The last few decades have witnessed a proliferation of tour operators and travel agencies offering educational tourism packages to school groups and college or university students. Concurrently, the rise in life-long learning and the growing cohort of healthy retirees with disposable income has also stimulated the industry. The demographic range of educational tourists from pre-school children to senior citizens provides endless opportunities for product development. Yet, while considerable discussion on the merits and practice of educational tourism can be found in the grey literature, for example: it reinforces classroom learning, brings the curriculum to life, connects students with potential employers, and develops curiosity and new perspectives, the academic study of educational tourism had not kept pace with industry growth.

This paper is structured around two primary objectives. Firstly, through the review and synthesis of current definitions of educational tourism, it develops an alternative, more inclusive conceptual model of the phenomenon. Secondly, it considers future directions for educational tourism research.

Ritchie's (2003) segmentation model of educational tourism is usually considered the international standard on the subject and has formed the basis of most theoretical development over the last decade and a half. However, adopting a market segment approach when defining educational tourism runs the risk of excluding sectors of the industry in which learning may be a significant activity. To avoid this, Pitman et al (2010) propose a process approach for defining educational tourism. Richards (2011) moves the concept further by suggesting that educational tourism be conceived as a transformative experience, while Stoner et al (2014) recommend that global citizenship be considered a learning outcome of educational travel. Combining research in the fields of educational tourism, international education, experiential learning and global learning, this paper calls for a rethinking of what constitutes educational tourism and proposes a conceptual process-driven and outcomes-based model of educational tourism. 
Building on Richards' (2011:27) observation of the increasing trend of merging work with leisure and tourism, a generic typology of educational tourism is presented as a means of hybridizing educational tourism with other sectors. The paper concludes with a discussion on why educational tourism is perfectly positioned to contribute towards fostering peace between people of different cultures and nationalities.

\section{Defining educational tourism}

\subsection{Domestic educational tourism}

Pitman et al's (2010:219) observation that the terms "tourism" and "education" are "problematic bedfellows" is fitting considering the lack of consensus regarding what actually constitutes educational tourism. Proponents usually concur that it involves travel away from one's home with either the primary or secondary purpose being to learn in a unique environment (Árnason, 2010; Pitman et al, 2010; Richards, 2011; Ritchie, 2003; Stoner et al, 2014). Beyond that, definitions of educational tourism vary.

Much of the literature attempts to define educational tourism from a technical perspective in terms of the industry sectors or segments it either encompasses or excludes. For example, Richards (2011:14) suggests that growth in educational tourism is a consequence of the fragmentation of cultural tourism, and that educational tourism is a separate niche from volunteer tourism, language tourism and creative tourism. In contrast, The City of Cape Town (2009:154) recommends considering educational tourism, volunteer tourism, backpacking and youth tourism as a single composite, owing to the close association between the four sectors. Bodger (in The City of Cape Town, 2009:70) suggests that educational tourism includes four subtypes of tourism: ecotourism, heritage tourism, rural/farm tourism and student exchanges between educational institutions. Ritchie (2003), on whose model much of the research in educational tourism has been based over the last decade and a half, also proposes that educational tourism comprise four segments, though instead of defining them according to subject matter, like Bodger, he defines three of his segments demographically while his fourth category is termed "edu-tourism"

Ritchie's (2003) segmentation model of educational tourism adopts an anthropological perspective being based on the motivational factors that drive tourists of different agegroups. According to him, educational tourism is defined by the desire to learn. In his model, learning may be either a primary or secondary motivator to travel (Ritchie, 2003:14) and learning may occur formally (using an expert or guide), or informally 
(independently or self-driven) (Ritchie, 2003:11). His conceptual model of the major segments of educational tourism is reproduced in Figure 1.

Figure 1: Ritchie's segmentation model of educational tourism

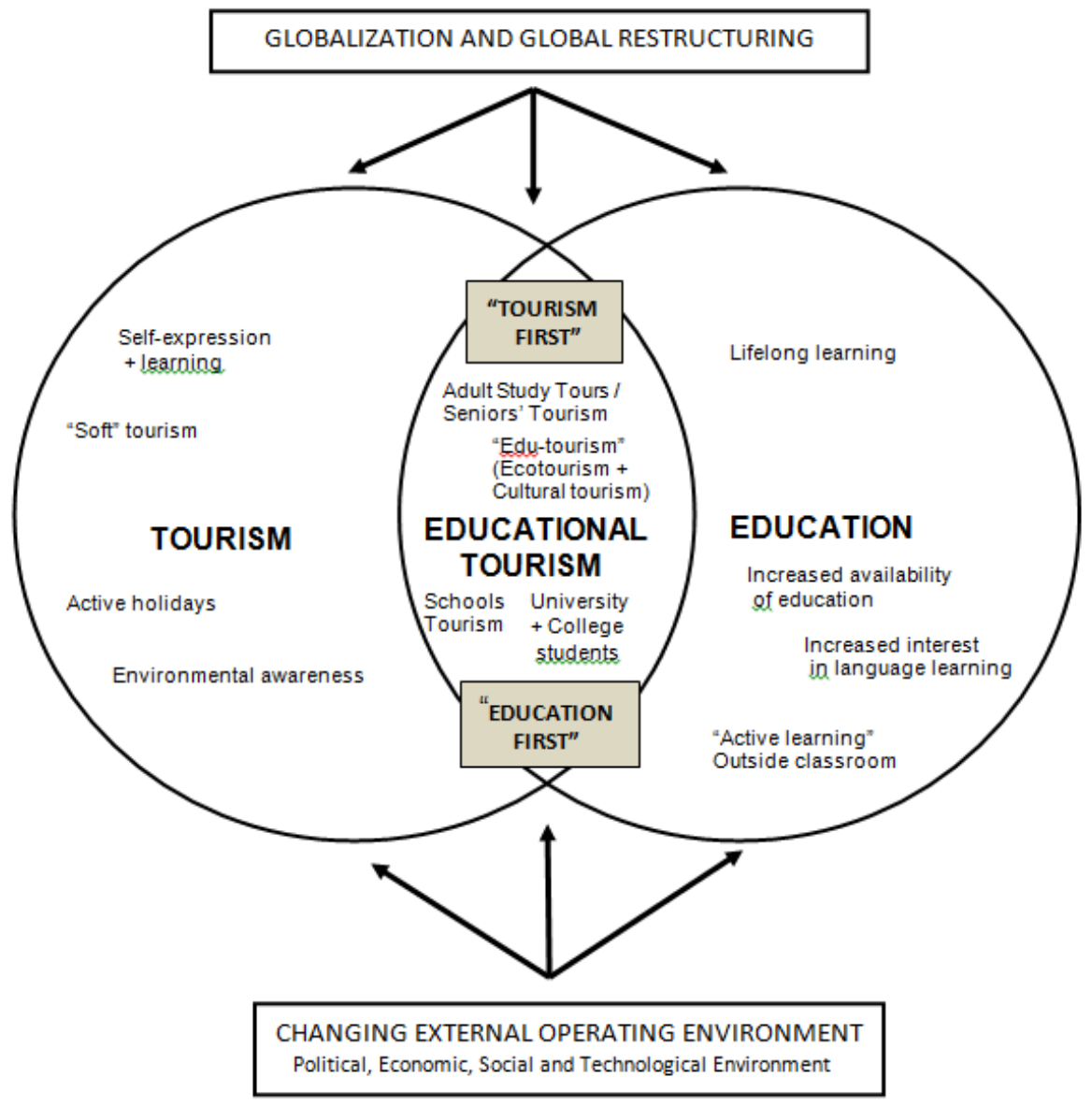

(Source: Adapted from Ritchie, 2003:13).

Although Ritchie's model helps conceptualise the overlap between education and tourism and has contributed to developing awareness of educational tourism as a niche sector, it has limitations. Adopting a "tourism first" or "education first" motivational dichotomy is problematic. For example, life-long learning is a primary motivational factor for many senior tourists (Pitman et al, 2010; Road Scholar, 2015), yet seniors' tourism in the model is positioned as a "tourism first" activity. Furthermore, defining motivational factors is difficult when people self-identify and may be particularly so in the case of school-based educational tourism. For example, whilst teachers would perceive a school trip as being primarily educational, children are more likely to view participation as primarily a fun experience and hence in Ritchie's model would be categorised as 
"tourism first". From an educational perspective, good learning at school level should be fun, making the need to differentiate in terms of education or tourism redundant. Furthermore, by defining educational tourism by the criterion of being motivated either primarily or secondarily by the desire to learn is particularly problematic when dealing with children. A child may have no desire to learn on a tour. Their participation could be motivated by the desire to be with a friend, to avoid some other less appealing activity, to avoid getting detention for non-attendance and so on.

By equating "formal education" with universities, colleges, foreign language schools and schools (Ritchie, 2003:11), Ritchie excludes other post-secondary professional, technical and vocational training activities, as well as creative pursuits and, what Richards (2011) terms: "informal" self-development experiences. Ritchie's lumping together of ecotourism and cultural tourism as "edu-tourism" also excludes a number of other potential sectors, such as: agri-tourism, heritage tourism and literary tourism.

Conceptualising education tourism as a process overcomes the limitation of sectorbased definitions. In an online survey of over 850 educational tourists, academics and tour operators in Australia, Pitman et al (2010:223) identified three key features of an educational tourism experience:

1. The trip was intentionally educationally focused.

2. The style of learning was experiential.

3. The trip was structured around an educational programme.

Educational tourism was described as "involving a deliberate and explicit learning experience" (Pitman et al, 2010:221). To be effective, it required active participation on the part of the educational tourists, an observation that concurs with that of Paige and Vande Berg (2012). The attitude of the tourist, in term of willingness to learn, was found to be more important for successful learning than any qualifications they might have. Reflective practices that took place on site or during the tourism experience were important for learning. In a departure from normal definitions of tourism, the process of educational tourism "extended beyond the actual touristic experience and encompassed pre- (and post-) travel considerations" (Pitman et al, 2010:234). Complementing Pitman et al's (2010) research, Árnason (2010) and Richards (2011) identifiy the need for the tourism experience to be structured at an educationally appropriate level for the educational tourist.

If one accepts the proposition that educational tourism is defined by the process of learning, that is the acquisition of knowledge and skills, then a number of other segments of tourism need to be included under the umbrella of educational tourism. Although Richards (2011) specifically excludes them in his definition of educational 
tourism, his explanations of what comprise creative tourism: "an exchange of knowledge and skills between guest and host" (Richards, 2011:35) and volunteer tourism: "fuelled by the desire to learn about other cultures" (Richards, 2011:36), should be both considered aspects of educational tourism. Similarly, spiritual tourism, which involves a personal journey of self-discovery and growth, should also be positioned within educational tourism.

Kolb's theory of experiential learning (Kolb, 1984) is referred to extensively in the literature to explain the process of learning associated with educational tourism (Stoner et al, 2014; Vance et al, 2011; Van 'T Klooster, 2014); international education (Tarrant et al, 2014; Paige \& Vande Berg, 2012), and global learning (De Mello, 2011; Merryfield et al, 2008). Kolb (1984) proposed the integration of four different but complementary styles of learning to achieve effective education. When experiential education informs the touristic learning experience, it provides an ideal pedagogy for promoting learning.

Pine and Gilmore (in Richards, 2011) introduce the concept of the "Experience Economy" as the next stage in the production of value. In essence, they describe how economies over the last two centuries have moved from the extraction of raw materials, to production of goods, then services, and that the next stage is the production of "unique experiences" (Richards, 2011:36). This concept is central to educational tourism. Educational tourists today tend to be better educated, more academically minded, have a higher disposable income, and are more concerned about the environment and cultures (Árnason, 2010; Pitman et al, 2010; Richards, 2011). Educational tourists increasingly demand an authentic, rather than mass produced experience (Richards, 2011:36) and are particularly wary of the commodification of cultures (Lyons et al, 2012). According to Richards, this shift in demand is associated with a more co-operative form of tourism, whereby the tourists and the tour providers "co-create the desired experiences" (Richards, 2011:38), a notion also identified by Pitman et al (2010).

In line with international educators, Van 'T Klooster (2014) adds a further requirement for effective educational tourism, namely the experience of difference. According to him, in order for learning to occur during educational travel, some degree of difference from the tourist's normal life experiences needs to be encountered.

\subsection{International educational tourism}

Educational tourism and international education share a common history. The process of travelling in order to learn is a feature of both and together they describe international educational tourism (IET). The theory of experiential learning can be applied to explain 
the manner in which learning occurs during IET. Global learning theory may be used to describe the generic, as opposed to subject-specific, desired outcomes of IET.

Unlike educational tourism which can be applied to all stages of life, international education is usually considered a tertiary-level educational phenomenon. Knight defines international education as: "the process of integrating an international, intercultural, or global dimension into the purpose, function or delivery of post-secondary education" (Knight, 2004:11). International education theory is well established in the literature and various conceptual models have been developed to describe the process by which students become more interculturally competent. Intercultural competence is associated with the development of skills and knowledge which enable one to communicate effectively and behave appropriately within cultural settings which are different from one's own culture (Deardorff \& Jones, 2012). Table 1 provides a summary of the similarities and differences between educational tourism and international education.

Table 1: Comparison of educational tourism and international education

\begin{tabular}{|c|c|c|c|}
\hline & $\begin{array}{l}\text { Educational } \\
\text { tourism (ET) }\end{array}$ & $\begin{array}{l}\text { International } \\
\text { education (IE) }\end{array}$ & Comment \\
\hline Origins & The Grand Tour & Academic pilgrims & $\begin{array}{l}\text { Different terms but shared origins in } \\
\text { the mid- } 17^{\text {th }} \mathrm{C} \text {. }\end{array}$ \\
\hline $\begin{array}{l}\text { Process of } \\
\text { learning }\end{array}$ & $\begin{array}{l}\text { Experiential } \\
\text { education }\end{array}$ & $\begin{array}{l}\text { Experiential } \\
\text { education }\end{array}$ & $\begin{array}{l}\text { Same process though theory } \\
\text { employed more in IE literature. }\end{array}$ \\
\hline $\begin{array}{l}\text { Educational } \\
\text { level applied }\end{array}$ & $\begin{array}{l}\text { From pre-primary } \\
\text { school to life-long } \\
\text { learning }\end{array}$ & $\begin{array}{l}\text { Only tertiary } \\
\text { education }\end{array}$ & $\begin{array}{l}\text { Overlap at tertiary level for students } \\
\text { studying abroad for one year or less. }\end{array}$ \\
\hline Strands & $\begin{array}{l}\text { International or } \\
\text { domestic } \\
\text { Day trips or } \\
\text { over-night tours }\end{array}$ & $\begin{array}{ll}\text { - } & \text { IE "at home" - } \\
\text { internationalising } \\
\text { the curriculum } \\
\text { - } \\
\text { - interss-border" IE } \\
\text { study } \\
\text { programmes }\end{array}$ & $\begin{array}{l}\text { ET is not concerned with } \\
\text { internationalising the curriculum } \\
\text { within schools. }\end{array}$ \\
\hline $\begin{array}{l}\text { Educational } \\
\text { outcomes }\end{array}$ & $\begin{array}{l}\text { - Global learning } \\
\text { - Specific } \\
\text { academic / } \\
\text { vocational } \\
\text { competencies }\end{array}$ & $\begin{array}{l}\text { Cross-cultural } \\
\text { competence } \\
\text { - Specific } \\
\text { academic / } \\
\text { vocational } \\
\text { competencies }\end{array}$ & $\begin{array}{l}\text { IE focused on enabling students to } \\
\text { function within inter-cultural settings; } \\
\text { ET does this plus it is hypothesized it } \\
\text { develops broader social and } \\
\text { environmental awareness potentially } \\
\text { leading to behavioural changes. }\end{array}$ \\
\hline $\begin{array}{l}\text { Economic } \\
\text { contribution }\end{array}$ & $\begin{array}{l}\text { - Some research } \\
\text { on contribution } \\
\text { of school trips to } \\
\text { local economies }\end{array}$ & $\begin{array}{l}\text { - "Export } \\
\text { education" is a } \\
\text { multi-billion dollar } \\
\text { global industry }\end{array}$ & $\begin{array}{l}\text { ET is very under-researched with } \\
\text { regards to its economic impact on } \\
\text { economies. }\end{array}$ \\
\hline
\end{tabular}

(Source: McGladdery, 2016 p.9) 
Scholarly development of educational tourism could benefit substantially from review of the international education literature.

Whereas a primary outcome of international education is the achievement of intercultural competence, global learning progresses personal development to a point where one considers one's role within a broader multi-cultural and environmental context. Bénekar et al (2014), Lilley (2014), Merryfield et al (2008), and Toumi et al (2008), suggest that values characteristic of global learning include: openness, tolerance, respect and a sense of responsibility towards self, others and the environment. The process of global learning, which in some of the literature is referred to as global citizenship education, is considered to follow a progression, from global awareness (the acquisition of knowledge), to global mindedness (a change in attitude or way of thinking associated with being more socially and environmentally aware), to global competence (associated with a change in behaviour that is more participatory and justice-orientated) (Tarrant et al, 2014).

\subsection{Reconceptualising educational tourism}

Integrating experiential learning theory with existing research in educational tourism and drawing from the closely aligned discipline of international education, a process-driven, outcomes-based model of educational tourism as a transformative experience is proposed (see Figure 2). According to this model, for effective learning to occur during educational tourism, clearly defined and learning-stage appropriate outcomes of the process need to be developed. Learning outcomes are traditionally written in three categories:

- Cognitive outcomes - measure what is to be learnt (knowledge acquired).

- Affective outcomes - measure attitudes, or ways of thinking, that may change.

- Behavioural outcomes - measure skills that will be developed.

The advantage of establishing outcomes is that they are measurable and hence can be evaluated and modified to affect effective learning.

The model encompasses all life-stages of tourists. To be effective, tourists need to experience difference from their usual frame of reference and the touristic experience needs to be educationally appropriate. Facilitation enhances learning. Finally, educational tourists should possess the desire to learn. Whilst acknowledging that children may not always be motivated to engage in learning, the model assumes that positive facilitation by a tour guide, teacher, or parent, will encourage learning. Educational tourism can range from informal journeys of self-discovery to formal 
academic credit-bearing courses. Experiential learning describes the process of learning and cognitive, affective and behavioural outcomes can be set against which learning can be assessed. When educational tourism is located within a different cultural or environmental context to that with which the tourist is familiar, or when it involves international travel, then global learning may be added as an additional objective of the model. Under those circumstances, outcomes can be developed which reflect the development of global awareness (cognitive outcomes), global mindedness (affective outcomes) and global competence (behavioural outcomes).

\section{Figure 2: A process model of educational tourism}

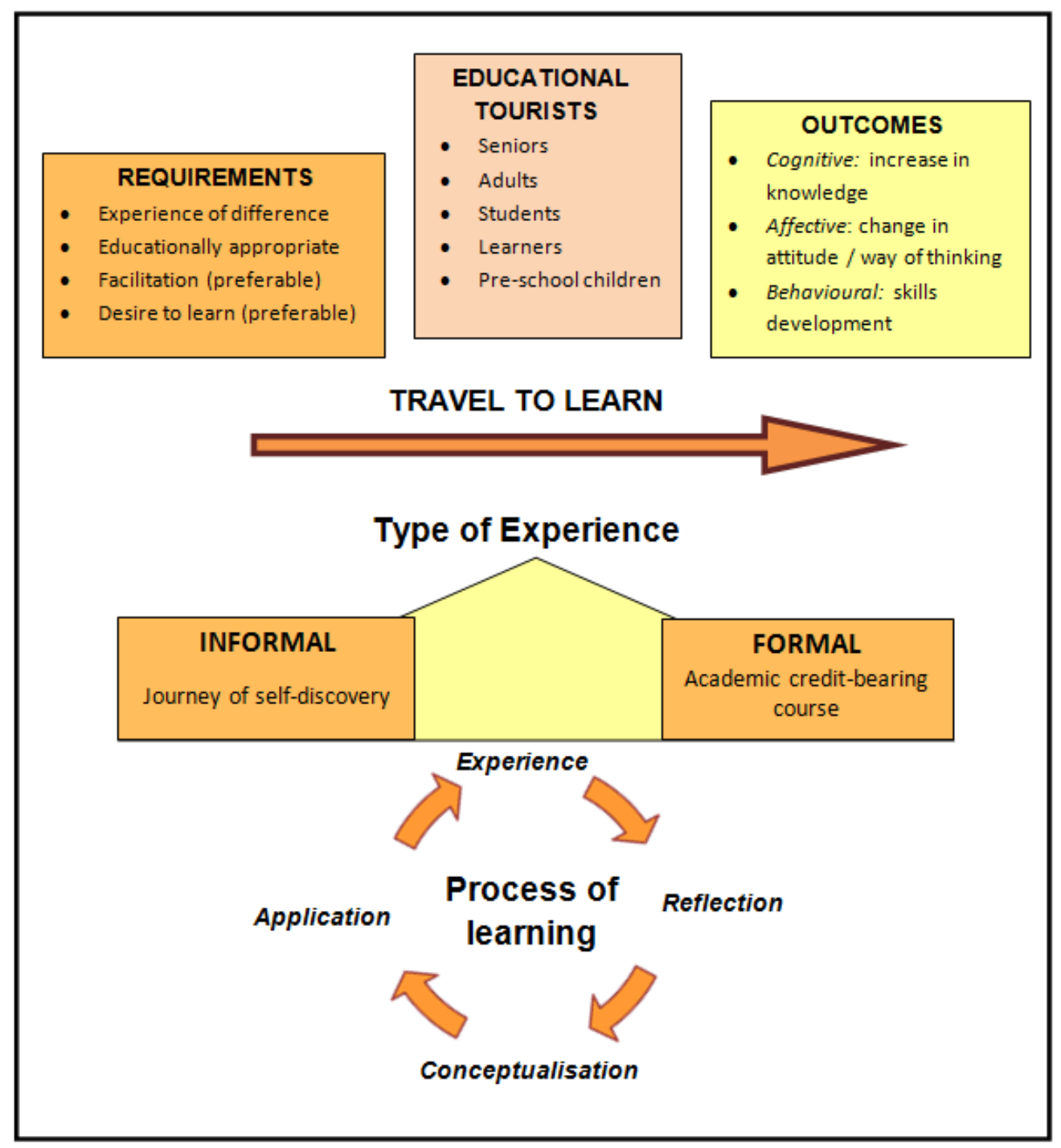

(Source: McGladdery, 2016 p.84) 
By reconceptualising educational tourism as a transformative process with clearly defined and measurable outcomes, rather than by the industry sector or subject matter of the tourism product, the model provides a framework upon which educational tourism activities can be developed and future research aligned. A process approach also demonstrates the possibility of hybridizing educational tourism with many different sectors of the tourism industry.

\section{Future directions for educational tourism}

Owing to educational tourism being such an under-researched sector of tourism, there are endless opportunities for research and development. This section commences with a review of transnational research in Europe aimed at understanding and developing the schools' tourism market. It then considers how IET could benefit from review of the international education industry. The suitability of educational tourism for hybridization with other segments of tourism as well as other industry sectors is then discussed. Finally, the potential of educational tourism to contribute to global peace and tolerance is presented.

\subsection{Understanding the schools' tourism market}

Considerable discussion exists in the grey literature regarding the merits and practice of schools' tourism and the industry has witnessed substantial growth and diversification over the last two decades. Despite this, the subject is under-researched in terms of its scope and specific nature (Campbell-Price, 2014; Stone \& Petrick, 2013). Poria and Timothy (2014) attribute the virtual absence of research on children's tourism to the need for specialist expertise in education and child psychology or development theories, and the difficulties of acquiring parent's and ethical committees' permission to work with children (Poria \& Timothy, 2014:94). This is supported by analysis of Stone and Petrick's (2013) review of 15 studies on the benefits accrued from travel experiences, which demonstrates that not one has children as the study population. Empirical research to test the claims in the grey literature, to define the scope of the subject and to establish schools' educational tourism as a segment of tourism worthy of academic enquiry, is required.

In an attempt to understand the size and interests of the schools' tourism market in Europe, the European Union's COSME (Competitiveness of Enterprises and Small and Medium-sized Enterprises) programme, in conjunction with WYSETC (World Youth and Student Educational Travel Confederation), is currently undertaking research for the EUMillenialsTOUR project. The EUMillenialsTOUR project is a collaboration of 20 
European nations with the ultimate objective of developing an "immersive learning / creative (transnational) trip addressed to the edu /school-trip tourism market" (EU, 2016:1; WYSETC, 2016). To date, five pilot trips have been undertaken (Boém, 2016). Results emanating from this initiative may well provide direction for future developments in school-based tourism in other regions of the world.

\subsection{Developing international educational tourism}

Most of the theoretical advances in international educational tourism have arisen in the closely aligned discipline of international education rather than tourism. Similarly, industry development of international educational tourism has not kept pace with that of international education. Modern international education, like international tourism, has become a global economic phenomenon, yet international educational tourism, which theoretically may be considered as the point at which the two industries overlap, is an underdeveloped sector. The export education industry has grown into a multi-billion dollar sector over the last few decades but is almost exclusively a pursuit of international education. Numerous countries have rebranded themselves to attract a greater share of the internationally mobile student market. This trend is particularly notable amongst the Anglo-American countries (Rhoades, 2016). The UK, Australia and New Zealand have centralised national marketing strategies to attract full-degree or diploma as well as shorter-term international students and the Institute of International Education provides a similar function in the USA. New Zealand, Australia and Finland have all branded themselves specifically to attract international students. Similarly, international education was identified as a priority sector for development in Canada's 2013 Global Markets Action Plan (De Wit, 2016).

While the provision of degrees to international students is obviously not the business of tourism, the industry could develop complementary products and services for those students. Moreover, the potential to develop non-university-based international educational tourism activities, within unique and diverse environments, appears largely unexplored. Theoreticians and practitioners of educational tourism could benefit from perusal of research emanating from international education.

\subsection{Investigating the potential for hybridization}

Richards' suggests that tourism products, services and experiences need to be reconceptualised using a hybrid model owing to an increasing trend of combining work with leisure and tourism (Richards, 2011:27). Educational tourism is ideally suited for this and a typology to facilitate the process is proposed in Figure 3. Based on the assumption that tourism products need to be developed that are educationally appropriate for participants, tourist life-stages are used as an equivalent to learning 
capability. The life-stage: student is deliberately used rather than the broader term: youth, in line with the fact that educational tourism is defined by the process of learning. Student educational tourism is thus conceived as a sub-segment of youth tourism. A learner is a child of primary or secondary school age. Guided by the research of Pitman et al (2010) and Paige and Vande Berg (2012), the process of learning is classified into either self-guided or facilitated. Additionally, facilitated learning is further divided into observational and experientially-based activities.

Figure 3: A learning process driven typology for educational tourism

\begin{tabular}{|c|c|c|c|}
\hline \multirow{2}{*}{$\begin{array}{l}\text { Tourist } \\
\text { life-stage }\end{array}$} & \multicolumn{3}{|c|}{ Dominant learning process } \\
\hline & Self-guided & Facilitated: observational & Facilitated: experiential \\
\hline \multicolumn{4}{|l|}{ Senior } \\
\hline \multicolumn{4}{|l|}{ Adult } \\
\hline \multicolumn{4}{|l|}{ Student } \\
\hline \multicolumn{4}{|l|}{ Learner } \\
\hline Pre-school child & & & \\
\hline
\end{tabular}

(Source: McGladdery, 2016 p.81)

The typology is a simple representation of the demographic categories of educational tourists and the processes by which learning may occur. By applying the typology to other tourism sectors, an educational component can be hybridized with the tourism product, hence diversifying and adding value to the tourism experience. The typology can also be used to integrate a touristic aspect with other non-tourism sectors. Furthermore, the typology provides a framework for comparative research of the effectiveness of different learning processes employed in educational tourism products.

\subsection{The potential of educational tourism to contribute to global peace}

The pressing need to integrate global learning into educational tourism products is highlighted by the findings of first global Humanitarian Index (Aurora Prize, 2016). One of the biggest concerns emanating from the survey was what the authors termed the "compassion gap" (Aurora Prize, 2016:15), namely the discrepancy that exists between what people say they know and feel about global issues compared with what they are prepared to do about them.

Educational tourism is perfectly positioned to address the "compassion gap". Global learning may be added as an objective of any form of educational tourism that 
encompasses either an intercultural or international aspect. Through thoughtful consideration of affective outcomes, educational tourism has the potential to address negative concerns around authenticity, the perpetuation of cultural stereotypes and the commodification of cultures, and in doing so, encourage the development of global tolerance and peace.

\section{Conclusion}

Research in educational tourism has not kept pace with industry development. In part, this stems from a lack of consensus regarding what the phenomenon comprises. By reconceptualising educational tourism as an experiential process with clearly articulated cognitive, affective and behavioural outcomes, this paper provides a framework upon which empirical research and product development may advance.

Studying schools' educational tourism is particularly problematic. School-based practitioners of educational tourism, who are rarely represented in the academic literature, need to share their experiences and articulate the challenges and benefits that accrue from conducting educational tours. The EUMillenialsTOUR project represents a transnational approach to the issue.

Practitioners and theoreticians of international educational tourism could draw on research emanating from the closely aligned discipline of international education.

When hybridized with other segments of tourism or industry sectors, educational tourism has the potential to add value.

UNESCO's Education for All global monitoring report encapsulates the paradox of modern society:

"While technological development contributes to greater interconnectedness and offers new avenues for exchange, cooperation and solidarity, we also see an increase in cultural and religious intolerance, identification-based political mobilization and conflict" (UNESCO, 2015:9-10).

Perhaps more so than any other sector of tourism, educational tourism has the greatest potential to start addressing these concerns. Aspects of global learning can be integrated into most, if not all, forms of educational tourism across all ages of tourists. It is time for educational tourism to move from the periphery of academic discourse. 


\section{References}

Árnason, P. (2010). "Thoughts on educational (geo) tourism". University of Iceland: Hornafjörour Rural Research Centre, Háskóli Islands.

Aurora Prize. (2016). Humanitarian Index. Yerevan, Armania.

Béneker, T, van Dis, H. \& van Middelkoop, D. (2014). "World-mindedness of students and their geography education at international (IB-DP) and regular schools in the Netherlands".

Interdisciplinary Journal of Development Education and Global Learning, Vol. 6 No. 3, pp. 5-30.

Boém, M.M. (2016). "EUMillenialsTour: Deliverable 7.6". available at: http://www.eumillennialstour.eu/downloads/D7.6_Webzine_n_3.pdf (accessed: 13 April 2017).

Campbell-Price, M. (2014). "International school trips: A critical analysis of multiple stakeholder perspectives". Unpublished PhD thesis, University of Otago, New Zealand.

City of Cape Town. (2009). Niche market study. Kamilla-SA Sport and Tourism Consultancy, Cape Town.

Deardorff, D.K. \& Jones, E. (2012). "Intercultural competence: an emerging focus in international education". In: Deardorff, D.K., de Wit, H. \& and Heyl, J.D. (eds). 2012. The SAGE handbook of international higher education. Sage, London.

DeMello, M.A. (2011). "The impact of study tours in developing global-mindedness among PK12 educators in southeastern Massachusetts". Doctoral thesis, Northeastern University, Boston.

De Wit, H. (2016). "The Institutional Race for International Tuition Dollars: Are the Costs Acceptable?" available at: http://wenr.wes.org/2016/05/placing-international-student-mobility-ina-quality-and-ethical-perspective/ (accessed: 6 May 2016).

EU. (2016). "COSME”. available at: https://ec.europa.eu/easme/en/cosme (accessed: 7 April 2016).

Knight, J. (2004). "Internationalisation remodelled: definitions, rationales, and approaches". Journal for Studies in International Education, Vol. 8 No.1, pp. 5-31. 
Kolb, D.A. (1984). Experiential learning: experience as the source of learning and development. Prentice-Hall, Englewood Cliffs.

Lilley, K. (2014). "Educating global citizens: translating the 'idea' into university organisational practice". International Education Association of Australia, Melbourne.

Lyons, K., Hanley, J., Wearing, S. \& Neil, J. (2012). "Gap year volunteer tourism: myths of global citizenship?" Annals of Tourism Research, Vol. 39 No. 1, pp, 361-378.

McGladdery, C.A. (2016). "The relationship between international educational tourism and global learning in South African high school learners". Unpublished doctoral thesis, University of Pretoria, Pretoria.

Merryfield, M.M., Lo, J. T-Y., Po, S.C. \& Kasai, M. (2008). "Worldmindedness: taking off the blinkers". Journal of Curriculum and Instruction, Vol. 2 No.1, pp. 6-20.

Paige, R.M. \& Vande Berg, M. (2012). "Why students are not learning abroad". In: Vande Berg, M., Paige, R.M. \& Lou, K.H. (Eds.). Student learning ABROAD: What are students are learning, what they're not, and what we can do about it. Stylus, Sterling, pp. 29-60.

Pitman, T.' Broomhall, S, McEwan, J. \& Majocha, E. (2010). "Adult learning in educational tourism”. Australian Journal of Adult Learning, Vol. 50 No. 2, pp. 219-238.

Poria, Y. \& Timothy, D.J. (2014). "Where are the children in tourism research?" Annals of Tourism Research, Vol. 47, pp. 93-95.

Rhoades, G. (2016). "US and UK universities skewed by their foreign recruits". available at: http://www.universityworldnews.com/article.php?story=20160323143056759 (accessed: 6 May 2016).

Richards, G. (2011). "Cultural tourism trends in Europe: a context for the development of Cultural Route"s. In: Khovanova-Rubicondo, K. (Ed.) Impact of European Cultural Routes on SMEs' innovation and competitiveness. Council of Europe Publishing, Strasbourg, pp. 21-39.

Ritchie, B.W. (2003). Managing educational tourism. Channel View Publications, Clevedon.. 
Road Scholar. (2015). "Explore the world with Road Scholar." available at: http://www.roadscholar.org/about/pos_page.asp (accessed: 21 March 2015).

Stone, M.J. \& Petrick, J.F. (2013). "The educational benefits of travel experience: A literature review". Journal of Travel Research, Vol. 52 No. 6, pp. 731-744.

Stoner, K., Tarrant, M., Perry, L., Stoner, L., Wearing, S. \& Lyons, K. (2014). "Global citizenship as an outcome of educational travel". Journal of teaching in travel and tourism, Vol. 14, pp. 149163.

Tarrant, M.A., Rubin, D.L. \& Stoner, L. (2014). "The added value of study abroad: fostering a global citizenry." Journal of Studies in International Education, Vol. 18 No. 2, pp. 141-161.

Tuomi, M.T., Jacott, L. \& U. Lundgren (2008). "Education for world citizenship: Preparing students to be agents of social change". Children's Identity and Citizenship in Europe Network, London.

UNESCO. (2015). Rethinking education: towards a global common good? UNESCO, Paris.

Vance, C.M.; Sibeck, G; McNulty, Y. \& Hogenauer, A. (2011). "Building global competencies through experiential coursework in international travel and tourism." Journal of International Education in Business, Vol. 4 No. 1, pp. 30-41.

Van 'T Klooster, E. (2014). "Travel to learn: the influence of cultural difference on competence development in educational travel". Unpublished doctoral thesis. Erasmus University, Rotterdam.

WYSETC. (2016). "EU MillenialsTour Project". available at: https://www.wysetc.org/2016/02/01/eu-millennialstour-project/ (accessed 7 April 2016). 